\title{
THE CANADIAN JOURNAL OF
}

Neurological Sciences

\section{LE JOURNAL CANADIEN DES}

Sciences Neurologiques

AN INTERNATIONAL JOURNAL / UN JOURNAL INTERNATIONAL

\section{REVIEW ARTICLE}

167 Excitation and Inhibition in Epilepsy

Jerome Engel, $\mathrm{Jr}$

\section{ORIGINAL ARTICLES}

175 The Efficacy of Retrograde Infusion with LY231617 in a Rat Middle Cerebral Artery Occlusion Model Nobuhiro Inoue, Y Lucas Yamamoto, Yasushi Ito, James A Clemens, Jill K Panetta and Mirko Diksic

184 Epidemiological Study of Ruptured Intracranial Aneurysms in the Saguenay-Lac-Saint-Jean region (Quebec, Canada)

Jean Mathieu, Louis Pérusse, Pierre Allard, Claude Prévost, Léo Cantin, Jean-Marie Bouchard and Marc DeBraekleer

189 Risk Factors for Peak Dose Dyskinesia in 100 Levodopa-treated Parkinsonian Patients Pierre J Blanchet, Pierre Allard, Laurent Grégoire, François Tardif and Paul J Bédard

194 Localizing Muscles for Botulinum Toxin Treatment of Focal Hand Dystonia C Geenen, E Consky and P Ashby

198 Perioperative Problems in Parkinson's Disease and Their Management: Apomorphine with Rectal Domperidone Néstor Gálvez-Jiménez and Anthony E Lang

204 Focal Midbrain Glioma: Long Term Survival in a Cohort of 16 Patients and the Implications for Management Mark G Hamilton, Carl Lauryssen and Neil Hagen

208 Triphasic Waves During Post-Ictal Stupor Abayomi Ogunyemi

213 Functional MRI Localization of Language in a 9-Year-Old Child RR Benson, WJ Logan, GR Cosgrove, AJ Cole, $H$ Jiang, LL LeSueur, BR Buchbinder, BR Rosen and VS Caviness, Jr

220 Listeria Spinal Cord Abscess - Clinical and MRI Findings Joseph Y Chu, Walter Montanera and Robert A Willinsky

32nd CANADIAN CONGRESS OF NEUROLOGICAL SCIENCES

June 24 - 28, 1997 Saskatoon, Saskatchewan
224 Headache and Scalp Edema in Sickle Cell Disease Giovanna Pari and Hyman M Schipper

227 Peridontoid Synovial Cyst Causing Cervico-medullary Compression Anthony M Kaufmann, William C Halliday, Michael West, Derek Fewer and Ian Ross

\section{NEUROLOGICAL PRACTICE}

231 Neurology and the Community - 1995 Richardson Lecture TJ Murray

(complete contents page i)

The official Journal of: The Canadian Neurological Society, The Canadian Neurosurgical Society,

The Canadian Society of Clinical Neurophysiologists, The Canadian Association for Child Neurology 
With Epival, it can be.

$\nabla$

Because Epival has been proven effective in primary generalized epilepsy, ${ }^{1 \cdot 3}$

as well as in partial seizures that secondarily generalize..$^{4.54}$

$\nabla$

Epival has been associated with little effect on learning and cognition. ${ }^{6}$

Drowsiness, visual disturbances, and ataxia are rarely noted ${ }^{7}$ - unlike phenytoin and carbamazepine. ${ }^{8}$ Epival is generally well tolerated in properly screened patients, ${ }^{7}$ causing less GI irritation (nausea, vomiting and indigestion) than valproic acid. ${ }^{9}$

$\checkmark$

With Epival, your epilepsy patients can be confident that they most likely appear to be just

like anyone else. Because there's more to anticonvulsant therapy than seizure control.

\section{THIS SHOULD BE THE ONLY INDICATION THEY HAVE EPILEPSY.}
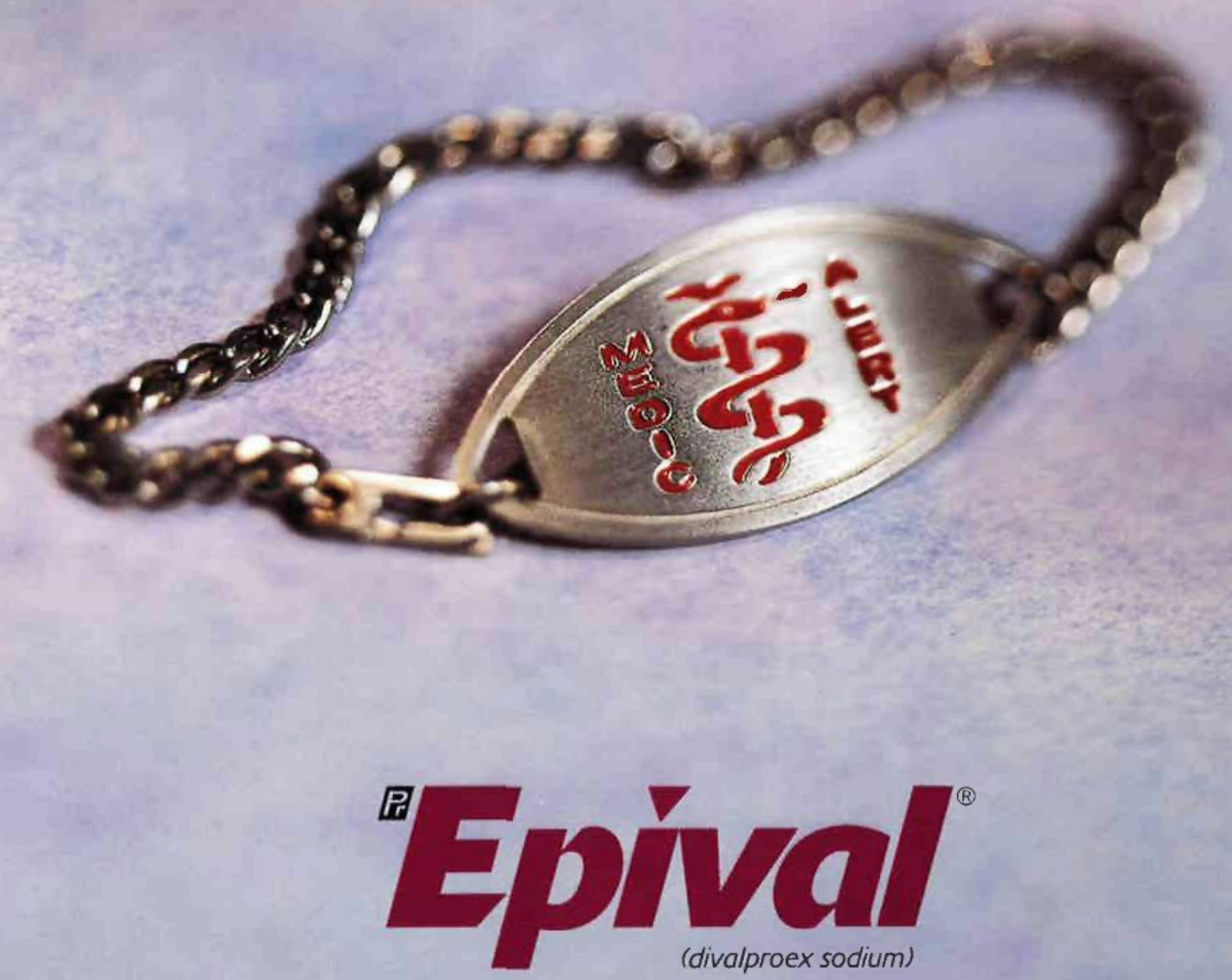

MELPS PUT PATIENTS BACK IN CONTROL.

- For use as sole or adjunclive therapy in the treatment of simple or complex absence seizures, including petit mal and is useful in primary generalized seizures with tonic-cionic manileslations. EPIVAL may also be used adjunctiveiy 


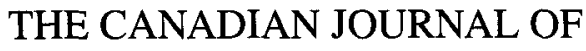 Neurological Sciences}

\section{LE JOURNAL CANADIEN DES}

\section{Sciences Neurologiques}

Review Article

ORIGINAL ARTICLES

NeUROLOGICAL PRACTICE

CORRESPONDENCE
167 Excitation and Inhibition in Epilepsy

Jerome Engel, Jr

175 The Efficacy of Retrograde Infusion with LY231617 in a Rat Middle Cerebral Artery Occlusion Model Nobuhiro Inoue, Y Lucas Yamamoto, Yasushi Ito, James A Clemens, Jill K Panetta and Mirko Diksic

184 Epidemiological Study of Ruptured Intracranial Aneurysms in the Saguenay-Lac-Saint-Jean region (Quebec, Canada)

Jean Mathieu, Louis Pérusse, Pierre Allard, Claude Prévost, Léo Cantin, Jean-Marie Bouchard and Marc DeBraekleer

189 Risk Factors for Peak Dose Dyskinesia in 100 Levodopa-treated Parkinsonian Patients Pierre J Blanchet, Pierre Allard, Laurent Grégoire, François Tardif and Paul J Bédard

194 Localizing Muscles for Botulinum Toxin Treatment of Focal Hand Dystonia $C$ Geenen, E Consky and P Ashby

198 Perioperative Problems in Parkinson's Disease and Their Management: Apomorphine with Rectal Domperidone Néstor Gálvez-Jiménez and Anthony E Lang

204 Focal Midbrain Glioma: Long Term Survival in a Cohort of 16 Patients and the Implications for Management Mark G Hamilton, Carl Lauryssen and Neil Hagen

208 Triphasic Waves During Post-Ictal Stupor Abayomi Ogunyemi

213 Functional MRI Localization of Language in a 9-Year-Old Child RR Benson, WJ Logan, GR Cosgrove, AJ Cole, H Jiang, LL LeSueur, BR Buchbinder, BR Rosen and VS Caviness, $J r$

220 Listeria Spinal Cord Abscess - Clinical and MRI Findings Joseph Y Chu, Walter Montanera and Robert A Willinsky

224 Headache and Scalp Edema in Sickle Cell Disease Giovanna Pari and Hyman M Schipper

227 Peridontoid Synovial Cyst Causing Cervico-medullary Compression Anthony M Kaufmann, William C Halliday, Michael West, Derek Fewer and Ian Ross

231 Neurology and the Community - 1995 Richardson Lecture TJ Murray

234 Re: Isolated Supranuclear Nerve Palsy: A Review of Nine Cases Asa J Wilbourn

234 Reply

Henry Berry

Books Received 235

Book Reviews 235

Notes and Announcements 242

Calendar of Events 243

Information for Authors xiv

Advertisers Index $\mathbf{x x i x}$ 


\section{THE CANADIAN JOURNAL OF \\ Neurological Sciences}

\section{LE JOURNAL CANADIEN DES Sciences Neurologiques}

Editor/Rédacteur en chef

James A. Sharpe TORONTO, ON

Associate Editors/Rédacteurs associés

Laurence E. Becker TORONTO, ON

John P. Girvin LONDON, ON

John R. Wherrett TORONTO, ON

\section{Past Editors}

Robert G. Lee CALGARY, AB

Robert T. Ross WINNIPEG, MB

(founding editor)

\section{Editorial Board/Conseil Scientifique}

Jack P. Antel MONTREAL, QC

Warren T. Blume LONDON, ON

Peter R. Camfield HALIFAX, NS

Pierre Duquette MONTRÉAL, QC

Peter J. Dyck ROCHESTER, MN, USA

Andrew A. Eisen VANCOUVER, BC

Julian T. Hoff ANN ARBOR, MI, USA

Renn Holness HALIFAX, NS

Peter Humphreys OTTAWA, ON

George Karpati MONTRÉAL, QC

Patrick L. McGeer VANCOUVER, BC

John H. Noseworthy ROCHESTER, MN, USA

C. Warren Olanow NEW YORK, NY, USA

William Pryse-Phillips ST. JOHNS, NF

Ali H. Rajput SASKATOON, SK

James T. Rutka TORONTO, ON

Alan M. Smith MONTRÉAL, QC

Garnette R. Sutherland CALGARY, AB

Jean-Guy Villemure MONTRÉAL, QC

Douglas W. Zochodne CALGARY, AB

Book Review Editor / Rédacteur de critiques de livres

Mary Anne Lee CALGARY, AB

News Editor/Rédacteur (nouvelles)

John W. Norris TORONTO, ON

Managing Editor/Administratrice adjointe

Sally A. Gregg CALGARY, AB

Publications Committee/Comité de Rédaction

Pierre Langevin STE-FOY, QC

Donald Brunet KINGSTON, ON

Mark Hamilton CALGARY, AB

Andrew Kertesz LONDON, ON
The official journal of: / La Revue officielle de:

The Canadian Neurological Society

La Société Canadienne de Neurologie

The Canadian Neurosurgical Society

La Société Canadienne de Neurochirurgie

The Canadian Society of Clinical Neurophysiologists La Société Canadienne de Neurophysiologie Clinique

The Canadian Association of Child Neurology

L'Association Canadienne de Neurologie Pédiatrique

The permanent secretariat for the four societies and the Canadian Congress of Neurological Sciences is at/

Le secrétariat des quatre associations et du Congrès Canadien des Sciences Neurologiques est situe en permanence à: 810, 906 - 12 Avenue S.W., Calgary, AB Canada T2R 1K7

The Canadian Journal of Neurological Sciences is published quarterly. The annual subscription rate is $\$ 65$ for members; $\$ 75$ for non-members in Canada: $\$ 85$ for USA and elsewhere. Residents, Interns, Pre- and Post-Doctoral Students $\$ 32.50$ per annum (members); $\$ 37.50$ per annum (non-members). Single copies $\$ 20$ each plus postage and handling. All manuscripts and communications should be sent to: Canadian Journal of Neurological Sciences, P.O. Box 4220, Station C, Calgary, AB Canada T2T 5N1. Courier to: $810,906-12$ th Avenue S.W.

Calgary, AB Canada T2R 1K7. Telephone (403) 229-9575; Fax (403) 229-1661. E-mail: cjns@canjneurolsci.org

COPYRIGHTO 1996 bY THE CANADIAN JOURNAL OF NEUROLOGICAL SCIENCES INC. No part of this journal may be reproduced in any form without the prior permission of The Canadian Journal of Neurological Sciences. Mailed under Publications Mail registration number 3307. Postage paid at Calgary, Alberta. This journal is indexed by Index Medicus, Excerpta Medica and Current Contents Clinical Practice and Life Sciences, Current Awareness in Biological Sciences.

Le Journal Canadien des Sciences Neurologiques est publie trimestriellement. L'abonnement annuel est de $65 \$$ pour les membres; $75 \$$ pour les non-membres au Canada; $85 \$$ pour les Etats Unis et ailleurs. Intemes, résidents, fellows pré et post doctoral; 32,50 \$ par annee (membres); 37,50 \$ par annee (non-membres). Copie simple: $20 \$$ plus affranchissement et manutention. Toutes les communications et les manuscrits doivent être adressés a Journal Canadien des Sciences Neurologiques, P.O. Box 4220, Station C, Calgary, AB Canada T2T 5N1. Par courrier: 810, 906 - 12th Avenue S.W., Calgary, AB Canada T2R 1 K7. Téléphone (403) 229-9575; Fax (403) 229-1661. E-mail cjns@canjneurolsci.org DROITS D'AUTEURQ 1996: THE CANADIAN JOURNAL OF NEUROLOGICAL SCIENCES INC. Aucune partie de ce Journal ne peut être reproduite, sous quelque forme que ce soit, sans la l'authorisation du Journal Canadien des Sciences Neurologiques. Posté sous permis de poste-publications no 3307. Port payé à Calgary. Aiberta. Le Journal est citế et indexé dans Index Medicus, Excerpta Medica et Current Contents - Clinical Practice et Life Sciences, Current Awareness in Biological Sciences.

Advertising representative/Représentant de publicité: Sally Gregg, Canadian Journal of Neurological Sciences 810,906 - 12 Ave. S.W., Calgary, AB Canada T2R 1K7 Tel (403) 229-9575 Fax (403) 229-1661

E-mail: cjns@canjneurolsci.org

Printer/Imprimeur:

McAra Printing Limited, 105, 2507 - 12th Street N.E., Calgary, Alberta T2E 7L5

ISSN 0317 - 1671 


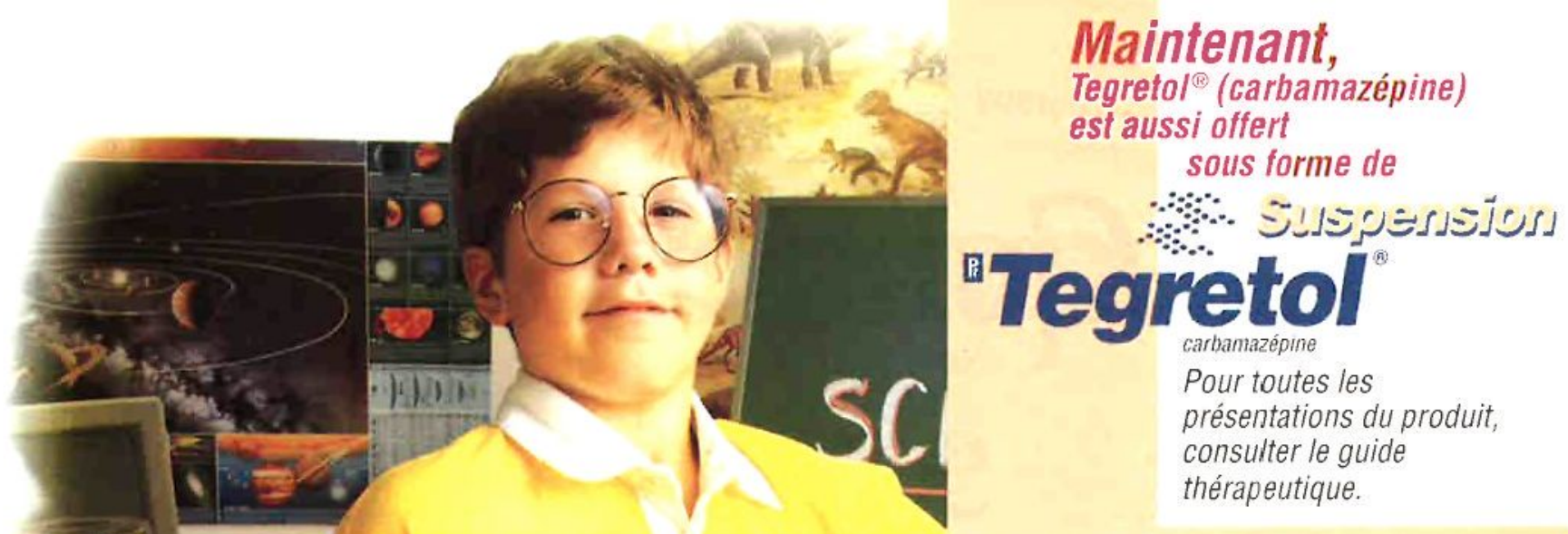

Maintenant, Tegretol ${ }^{\circledR}$ (carbamazépine) est aussi offert

sous forme de

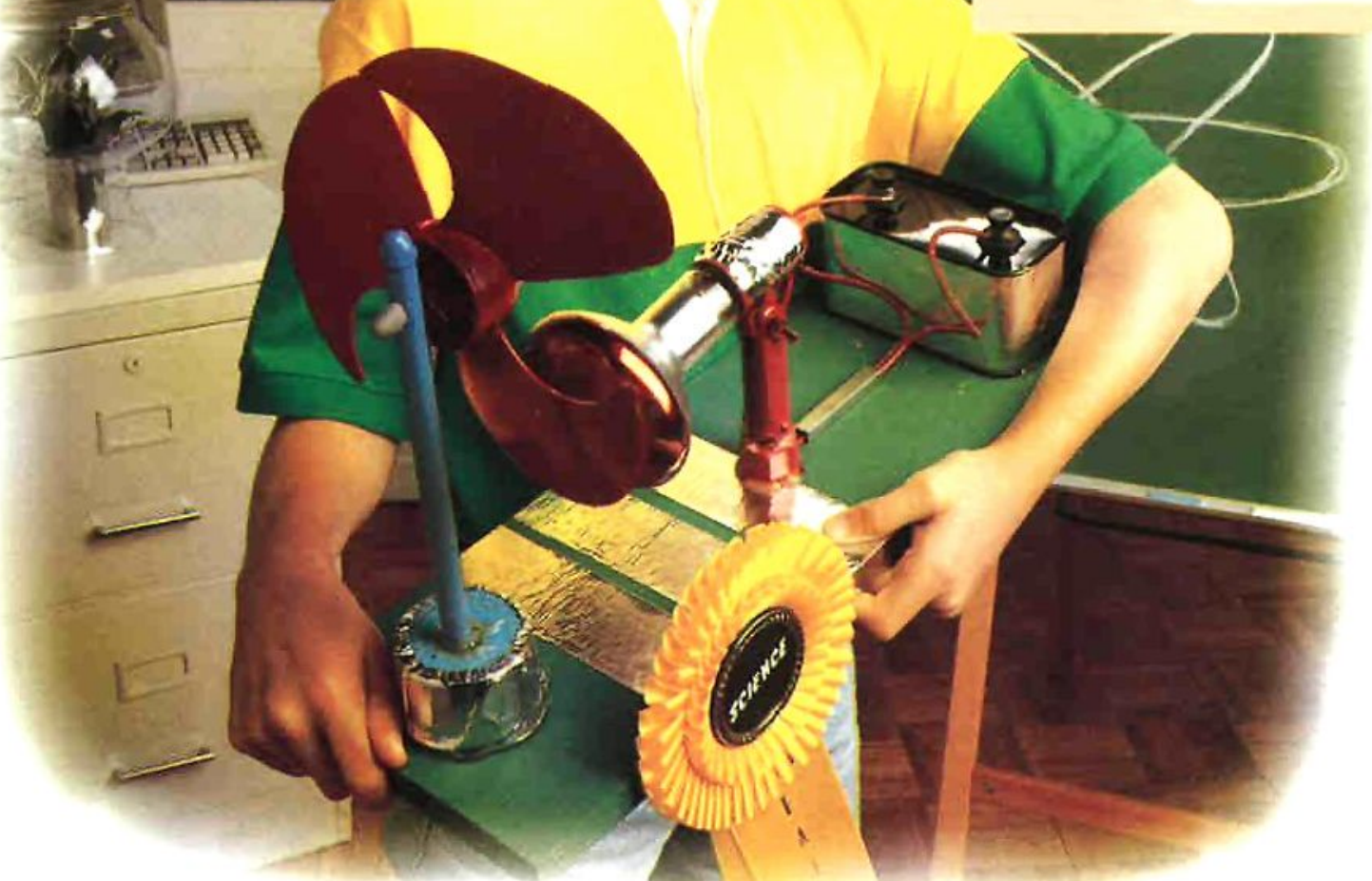

\section{On peut facilement reconnaître le jeune patient épileptique traité au Tegretol CR.}

\section{Excellent contrôle des crises}

ETegretol ${ }^{*} \mathrm{CR}$ (carbamazépine à libération contrôlée) maîtrise les crises chez de nombreux patients, causant peu d'impact sur la fonction cognitive ${ }^{1.2}$. Tegretol CR permet à de nombreux patients de penser clairement et de donner le meilleur d'eux-mêmes ${ }^{1,2}$.

\section{Taux sanguins uniformes}

Tegretol CR cause moins de "hauts et de bas" dans les taux sanguins que le Tegretol conventionnel. Les effets secondaires sont ainsi réduits et le modèle de fonction cognitive est plus stable.

Leffer indésiable le plus connmunément signalé, lié a la carhannzépne. est la sumbolence. Un tel effer ne se manifeste hahituellement quic durant la phase antuale du traitement ' mans on peut réduire son importance en aủninistrant de la carbanazépinc à libération contrôlée (TEGRETOL.CR)

\section{Posologie b.i.d. commode}

Lorsque vous instituez ou remplacez un traitement, pensez au Tegretol CR. Il est présenté en comprimés à $200 \mathrm{mg}$ et $400 \mathrm{mg}$ facilement divisibles pour une plus grande souplesse d'administration et améliorer

l'observance du patient.

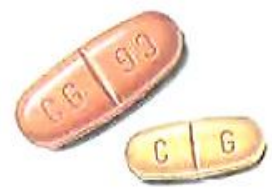

\section{TEGRETOL CR.}

Aide les épileptiques à réaliser leur plein potentiel. 


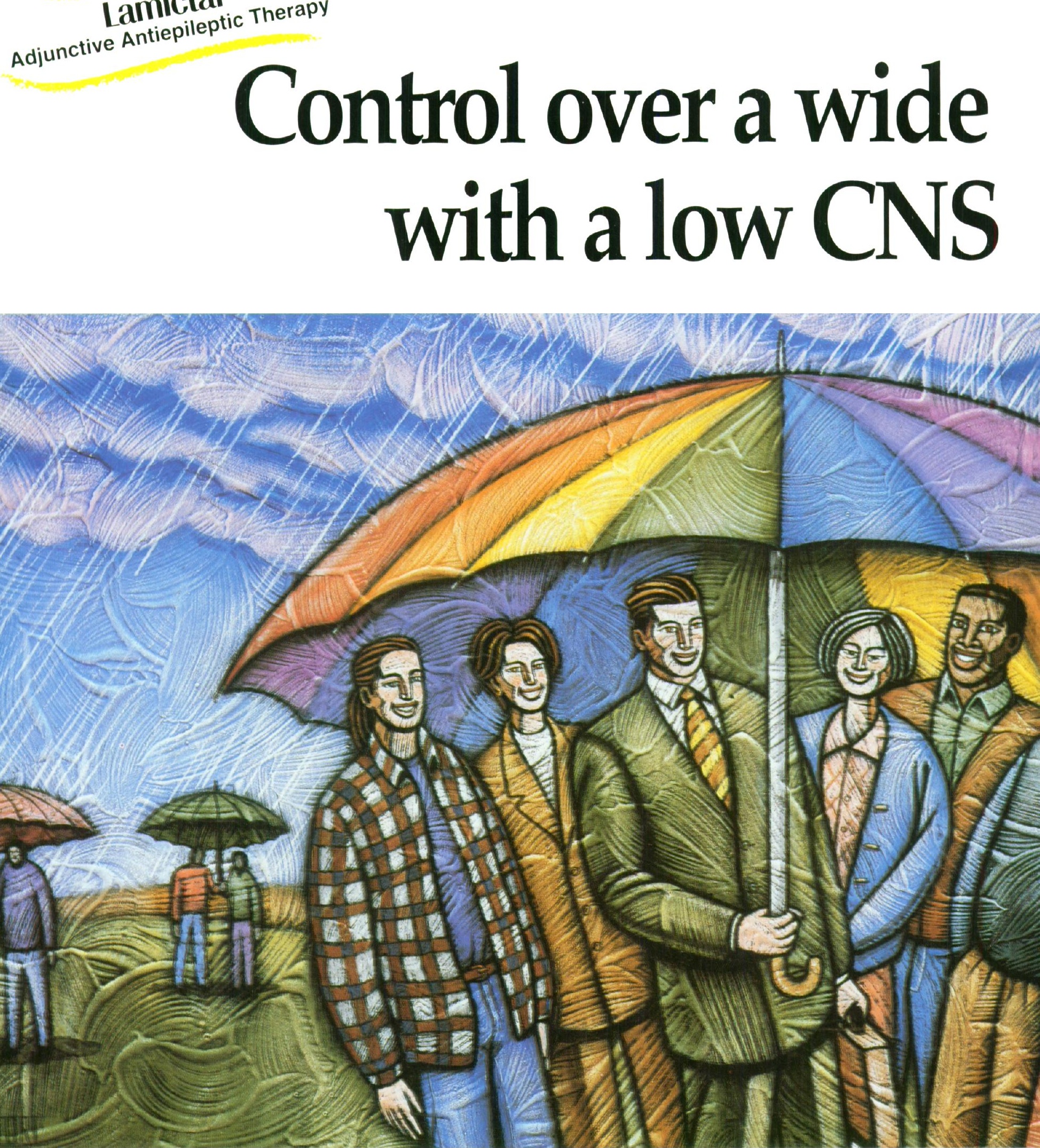

${ }_{\text {Withdrawal rates }(\geq 0.6 \%)}$ : dizziness $2.4 \%$, headache $1.3 \%$, nausea $1.3 \%$, blurred vision $1.1 \%$, rash $1.1 \%$, diplopia $0.7 \%$, ataxia $0.6 \%$. If there is any unexplained rash, fever, flu-like symptoms or worsening of seizure control, then hepatic, renal and clotting parameters should be monitored. See Product Monograph for recommendations when prescribing for geriatric patients and for patients with impaired renal and/or liver function. Serious skin-related events may be related to rapid initial titration of dosing and use of concomitant valproic acid.

GlaxoWellcome

Glaxo Wellcome Inc.

${ }^{(1)}$ Registered trademark of The Wellcome Foundation Limited. Glaxo Wellcome Inc. licensed use. 


\section{Sooner or later, every migra again. Imitrex ${ }^{\circ}$ believes}

A patient who complains about migraine is also complaining about a disrupted life. Indeed, research shows that in at least $31 \%$ of attacks, migraine sufferers cannot continue with their daily activities.

That's where Imitrex ${ }^{\circledast}$ comes in. For most
Unlike conventional remedies, it has not been shown to cause medication-induced headache ${ }^{3,6-8}$ Its adverse events are generally well tolerated, quickly resolved and usually non-threatening when explained to the patient." ${ }^{* 3,7,9}$ Imitrex ${ }^{\oplus}$ may be more expensive, but patients, Imitrex can bring

complete relief between 90

minutes and 2 hours, versus up to

9 hours for the usual treatments..$^{2,3}$

Imitrex treats all the symptoms

of migraine. ${ }^{* 35}$

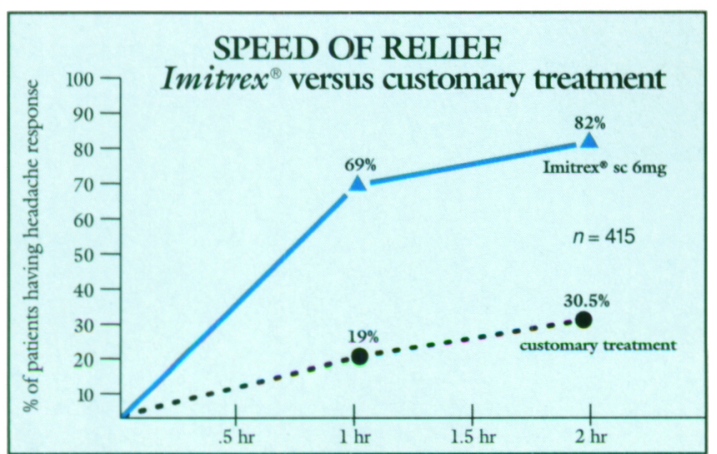

over 250,000 Canadian patients

continue to choose it for

migraine relief. ${ }^{10}$

The successful use of

Imitrex ${ }^{\circledast}$ is most likely in patients

who understand its common 


\section{ine sufferer will feel normal}

it should be sooner.

side effects, and who know when the drug should be used." ${ }^{*+11}$ Imitrex ${ }^{\oplus}$ should be taken at the start of a debilitating attack, and may also be used after the failure of conventional treatments (except ergotaminecontaining preparations) ${ }^{3}$
Most patients have attacks that limit normal function. ${ }^{1,12}$ So give your patients ${ }^{\dagger}$ the option of using Imitrex $x^{\oplus}$. It's a proven route to a fast recovery. ${ }^{2}$

For more information about Imitrex, please call 1-800-268-0324.
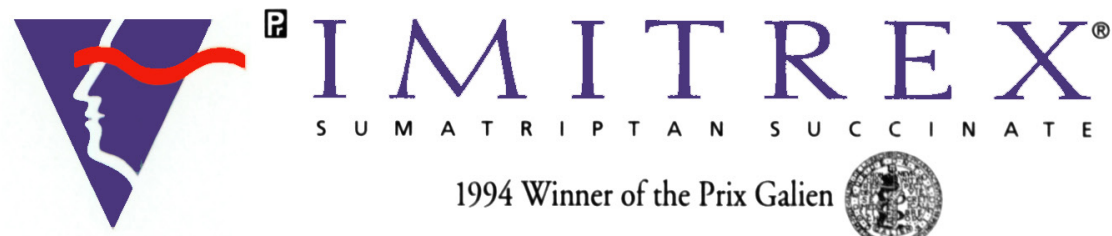

1994 Winner of the Prix Galien

\section{A faster way back.}

Glaxo

\begin{tabular}{|l|}
\hline PAAB \\
\hline CCPP \\
\hline
\end{tabular}

"Customary treatments include simple analgesics, combination analgesics, ergot derivatives, NSAIDs, narcotics, antiemetics, others. ${ }^{2}{ }^{* *}$ Head pain, nausea, vomiting, photophobia and phonophobia. ${ }^{3 * *}$ Fatigue dizziness, nausea and vomiting have been reported. These side effects are usually mild to moderate in intensity, transient and resolve within 45 minutes of s.c. administration and within two hours of oral administration. mitrex $\circledast$ has been associated with transient chest pain and tightness which may mimic angina pectoris. Only in very rare cases have the symptoms been associated with ischaemic ECG changes. If chest symptoms persist, patient should immediately consult physician. ${ }^{\dagger}{ }^{\dagger}$ Contraindicated in patients with ischaemic heart disease, angina pectoris including Prinzmetal angina, previous myocardial infarction and uncontrolled hypertension. 3 /mitrex is a selective 5 -HT, - like receptor agonist ${ }^{3}$ 


\section{When She Can't Remember Your Name,}

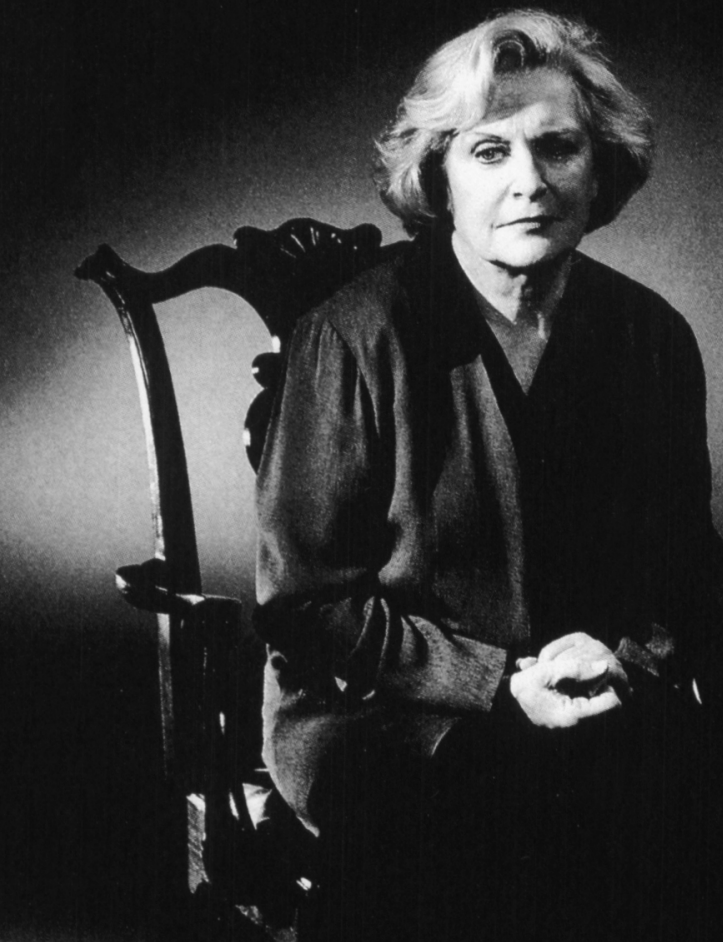

\section{Remember Ours.}

Alzheimer Disease is a degenerative brain disorder that destroys vital brain cells. It affects over $1 / 4$ million Canadians. And that's not including the people who love them.

Slowly, the disease steals away your ability to think, understand, remember, communicate, or to perform the simplest tasks, leaving you completely dependent.

There is no known cause, nor is there a cure.

But there is help and there is hope.

Alzheimer Canada is a national organization dedicated to helping those affected by the disease, as well as their caregivers. We also conduct research into possible causes, treatments and a cure, so that we can put an end to this killer disease.

If someone you love has Alzheimer Disease, there is a place to turn.

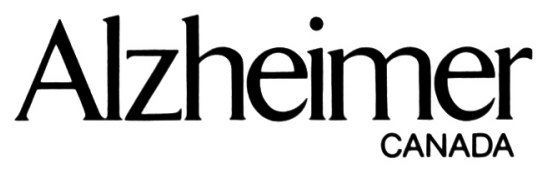

Help for Today. Hope for Tomorrow.

Contact the Alzheimer organization in your area or Alzheimer Canada at 1320 Yonge Street, Suite 201, Toronto, Ontario M4T 1X2 Tel: (416) 925-3552 
When phenytoin or carbamazepine fail to provide adequate seizure control in adult partial seizures...

\section{ADD NEURONTIN}
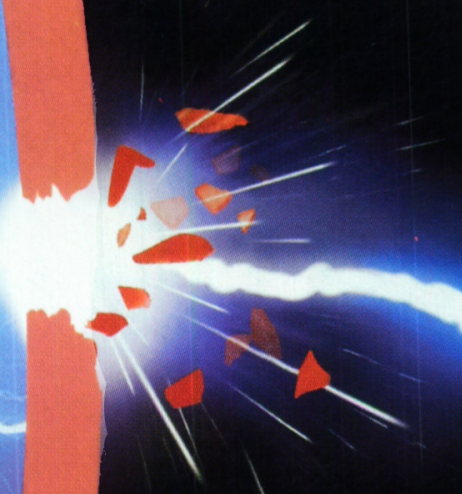

No pharmacokinetic drug interactions with standard anticonvulsants have been observed with Neurontin. Thus, it is easy to use as adjunctive therapy with existing antiepileptic drugs.'

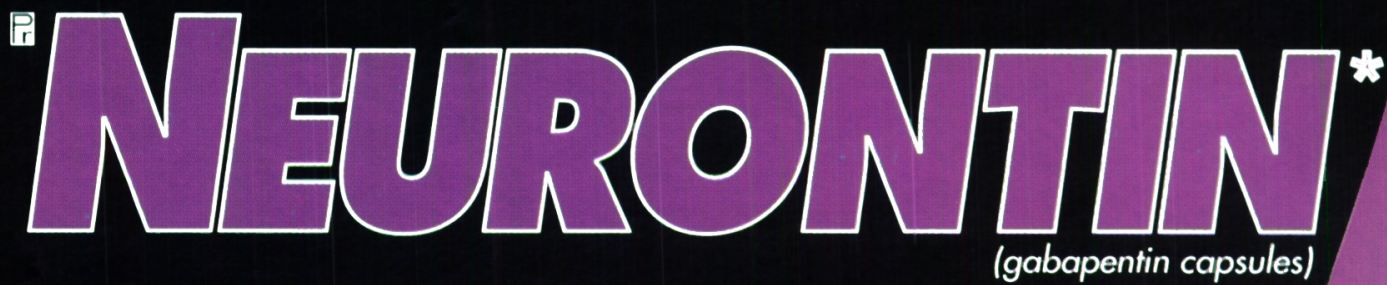

\section{Easy to add-on}

Neurontin is indicated as adjunctive therapy for the management of patients who are not satisfactorily controlled by conventional therapy. The most commonly observed adverse events not seen at an equivalent frequency in placebo-treated patients were somnolence, dizziness, ataxia, fatigue, nystagmus and tremor. Since Neurontin was administered most often in combination with other antiepileptic agents,

it was not possible to determine which agent(s) was associated with adverse events.

\section{(B) PARTE-DAVIS}

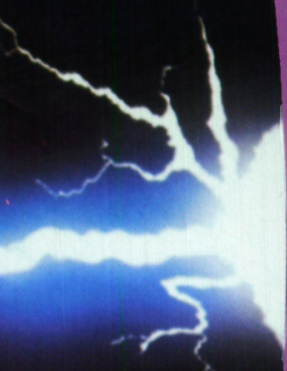



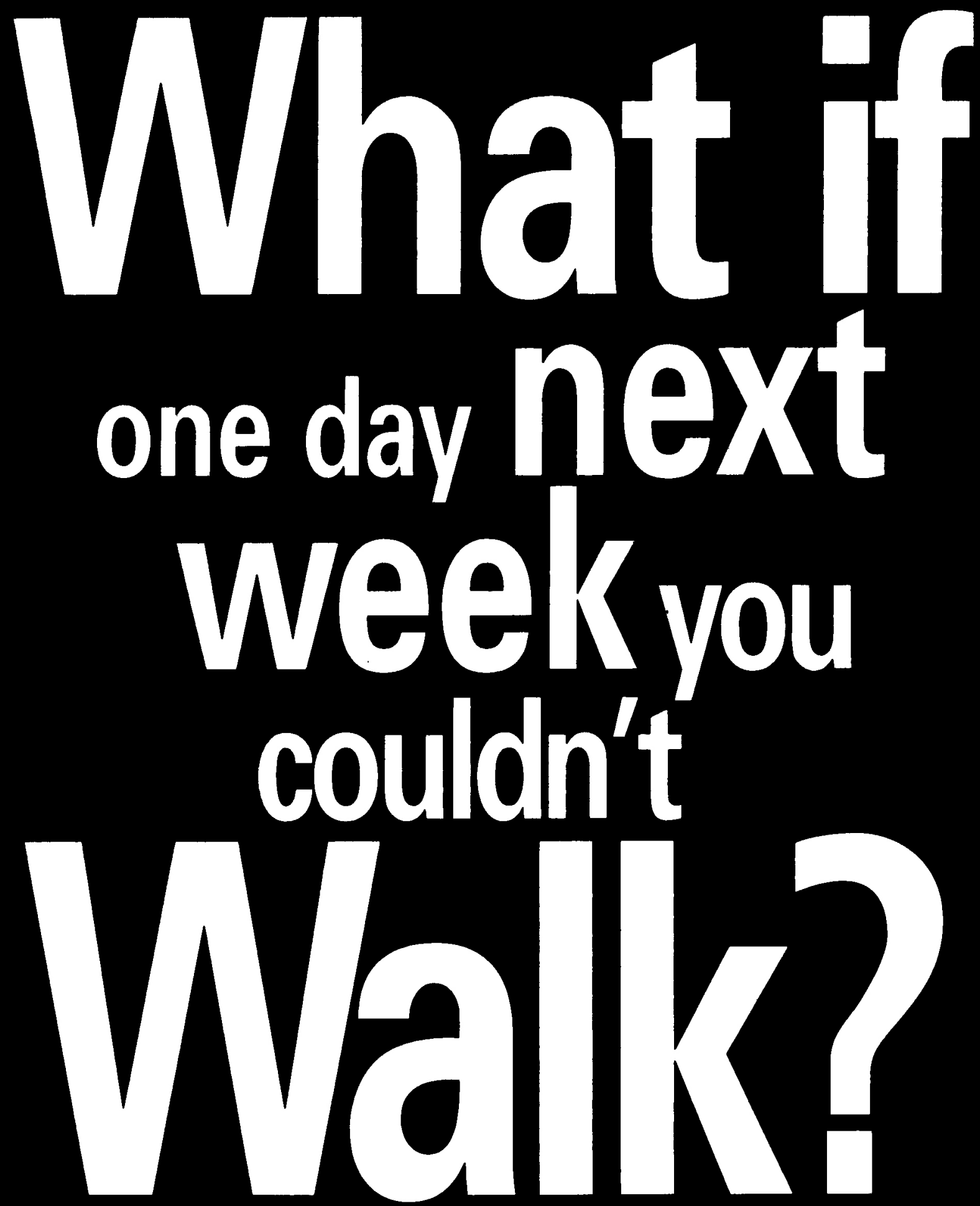

Or maybe you couldn't speak clearly. Or your vision was blurred. That's what it's like to live with multiple sclerosis, an unpredictable disease of the central nervous system. Things you take for granted can become impossible and you don't know when or where or if it will strike again. But the research and services programs of the Multiple Sclerosis Society of Canada are providing some answers. With your help, we can connect with a cure. 1-800-288-7582 Multiple Sclerosis 


\section{Introducing \\ "BETASERON}

The first treatment for relapsing/remitting multiple sclerosis

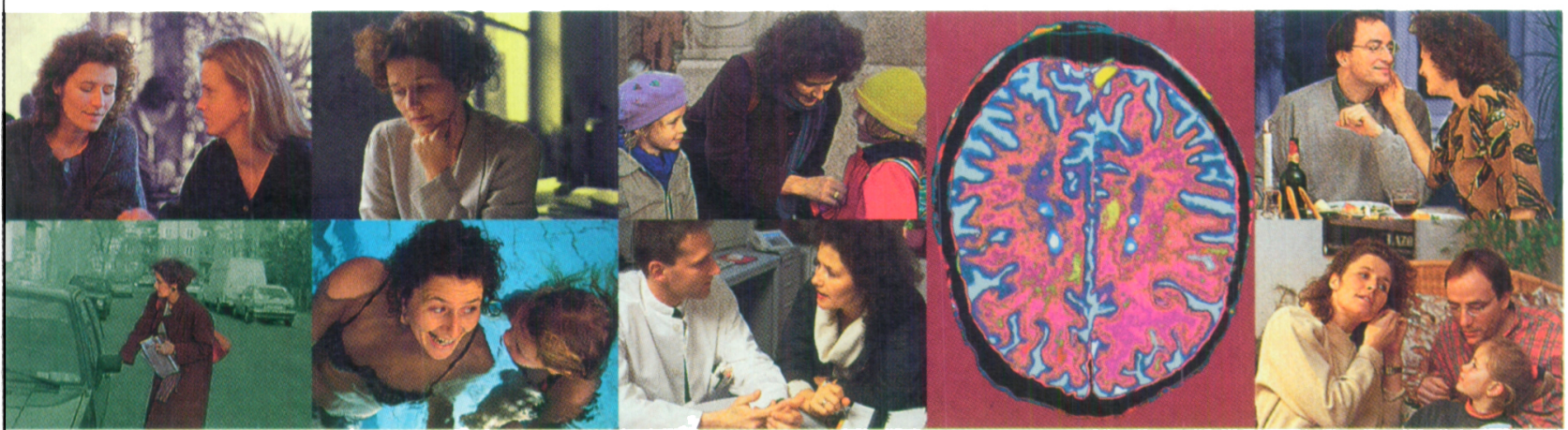

Clinical trials have shown that:

- The frequency of exacerbations was reduced by approximately $30 \%^{I}$

- Moderate and severe exacerbations were reduced by $50 \%^{1}$

- Disease activity, as measured by MRI, was reduced significantly ${ }^{2}$

- There was a low incidence of serious side effects ${ }^{t}$

- Patient education about common side effects such as injection-site reactions and flu-like symptoms is key to compliance

Over 40,000 patients treated to date ${ }^{3}$ 
Lamictal
Traitement antiépileptique d'appoint

\section{La maîtrise d'un vasteéven un profil discret d'effets}

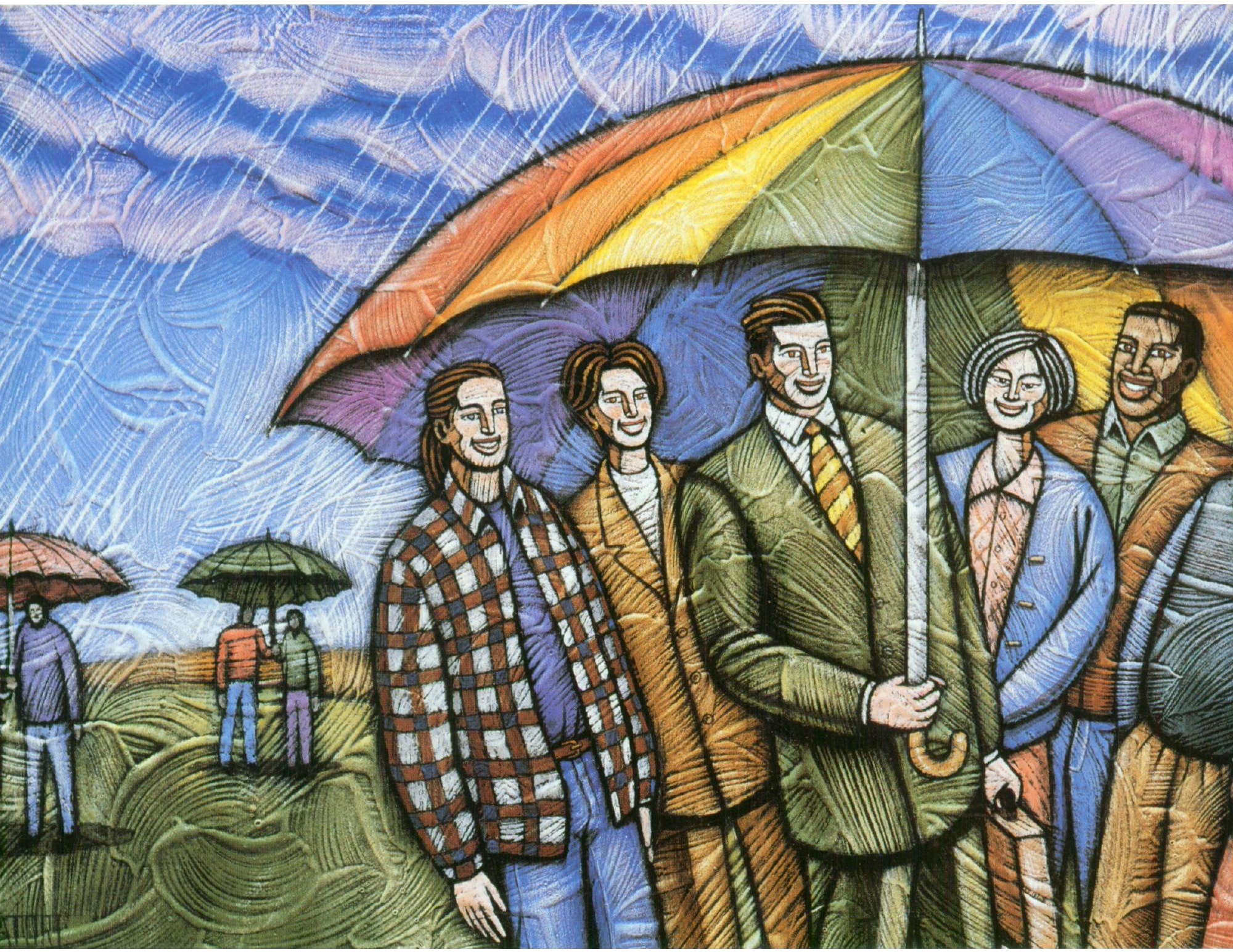

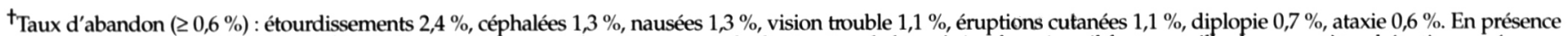
d'éruption cutanée inexpliquée, de fièvre, de symptômes pseudo-grippaux, ou de diminution de la maîtrise des crises, il faut surveiller les paramètres hépatiques, rénaux ou

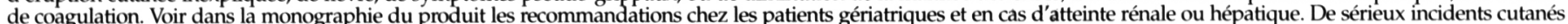
peuvent être causés par un ajustement posologique initial rapide et l'emploi concomitant d'acide valprö̈que.

†Comme avec la plupart des autres antiépileptiques, avant de prescrire LAMICTAL, vérifier dans la monographie du produit les risques d'interaction médicamenteuse avec d'autres antiépileptiques.

\section{GlaxoWellcome}

\section{Glaxo Wellcome Inc.}

d'affaires du Quebec

${ }^{\circ}$ Marque déposée de The Wellcome Foundation Limited, Glaxo Wellcome Inc., usager inscrit. 


\section{tail de types de crises avec secondaires sur le SNC}

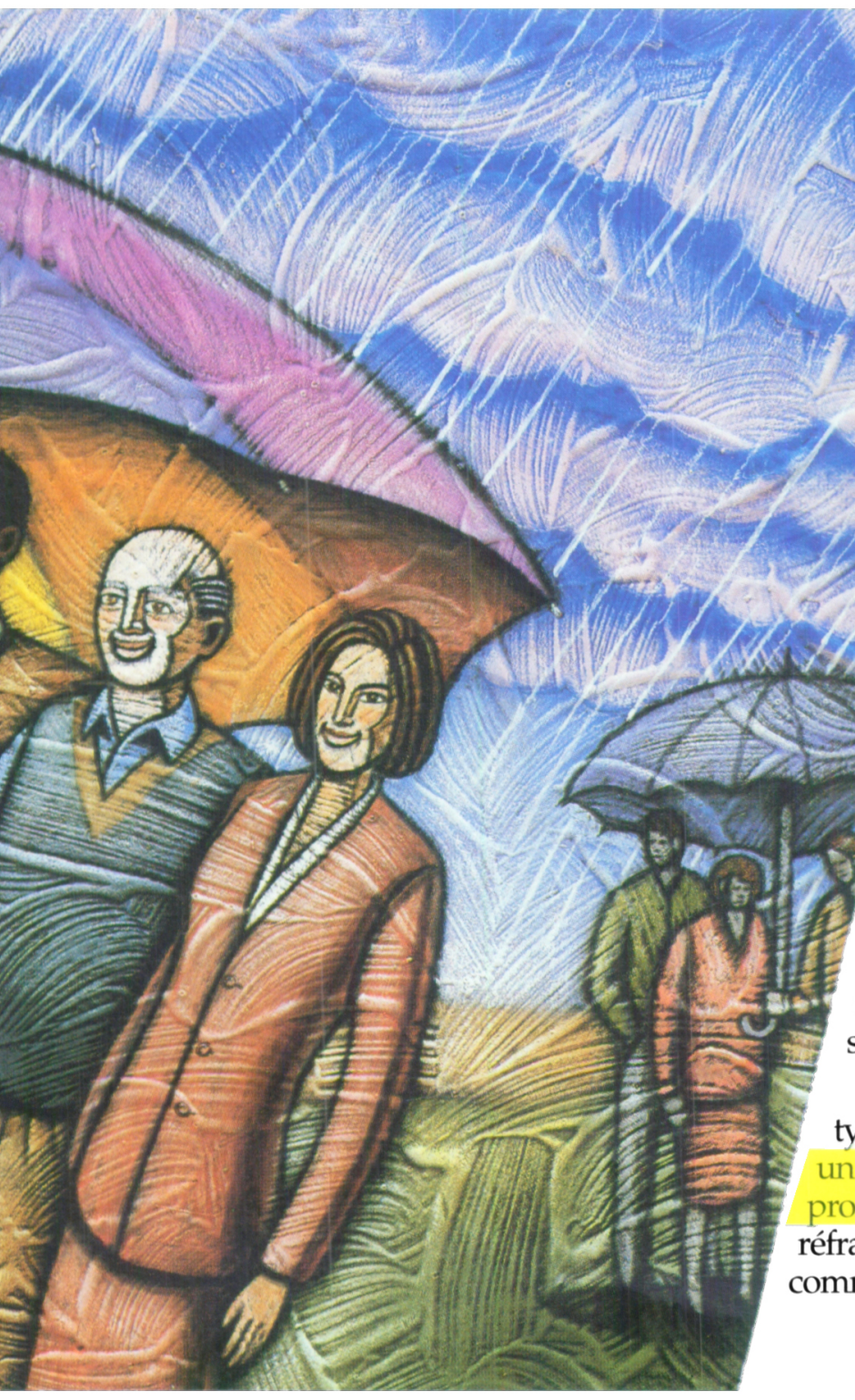

De nombreux patients souffrant d'épilepsie dans un vaste éventail de types de crises ne sont pas contrôlés de façon satisfaisante par les traitements conventionnels ${ }^{1}$. Maintenant, il y a LAMICTAL, un nouvel antiépileptique inédit sans parenté chimique avec aucun autre antiépileptique actuel ${ }^{1,2}$.

Les essais cliniques et l'expérience mondiale acquise chez plus de 140000 patients $^{3}$ ont montré qu'en traitement d'appoint, LAMICTAL offre une activité étendue dans le traitement de l'épilepsie chez les patients qui ne sont pas contrôlés de façon satisfaisante avec les traitements conventionnels ${ }^{1-24}$. En fait, LAMICTAL a suprimé les crises ${ }^{46,25}$ ou diminué leur fréquence ${ }^{1,6,10,15-17,23,25}$ et leur gravité chez jusqu'à $65 \%$ des patients ${ }^{1,6,16,23,25}$. Chez des volontaires en santé, LAMICTAL a présenté un profil d'effets secondaires sur le SNC plus favorable que la phénytoïne ${ }^{26}$. L'incidence de somnolence a été de $13 \%$ pour LAMICTAL par rapport à $12 \%$ pour le placebo dans les résultats combinés de quatre études à double insu contrôlées par placebo 7 . De plus, la plupart des patients sous LAMICTAL n'éprouveront pas d'effets indésirables qui affectent le $\mathrm{SNC}^{5+}$. Un plus grand nombre de vos patients réfractaires se sentiront donc mieux sous LAMICTAL ${ }^{6,23}$.

LAMICTAL exerce une activité dans un vaste éventail de types de crises. Vous pouvez maintenant offrir à vos patients un médicament caractérisé par une tolérabilité éprouvée et un profil discret d'effets indésirables sur le $\mathrm{SNC}^{+}$. Pour vos patients réfractaires, choisissez LAMICTAL - en 25, 100 ou $150 \mathrm{mg}-$ comme votre premier traitement $\mathrm{d}^{\prime}$ appoint ${ }^{\ddagger}$.

\section{Lamictal}




\section{INFORMATION FOR AUTHORS}

The Canadian Journal of Neurological Sciences publishes original articles in neurology, neurosurgery and basic neurosciences. Manuscripts are considered for publication with the understanding that they, or the essence of their content, have not been published elsewhere except in abstract form and are not under simultaneous consideration by another journal. Articles undergo peer review. Manuscripts should be submitted to:

James A. Sharpe

Editor

Canadian Journal of Neurological Sciences

P.O. Box 4220, Station C

Calgary, AB Canada T2T 5N I

\section{Manuscript Preparation}

- Submit five high quality copies of the manuscript and original illustrations. Papers will be accepted in English or French. Manuscripts must be double spaced throughout including references, tables and legends for illustrations. Margins of at least $25 \mathrm{~mm}$ should be left on all sides.

- After a paper has been reviewed, the author will be requested to submit four copies of the revised manuscript, including illustrations and a computer diskette ( $31 / 2$ " or $51 / 4$ " size) containing the article. Identify clearly first author's name, file name, word processing program and version, and system (i.e. DOS or Mac). Clearly indicate the order and importance of headings.

- For detailed instructions regarding style and layout refer to "Uniform requirements for manuscripts submitted to biomedical journals". Copies of this document may be obtained by writing to the Journal office, but the main points are summarized here. Articles should be submitted under conventional headings of introduction, methods and materials, results, discussion, but other headings will be considered if more suitable. Pages of text should be numbered consecutively.

- A title page should identify the title of the article which should be no more than 80 characters including spaces; name of institution(s) from which the work originated; and the name, address, telephone, and fax number of the corresponding author.

- Abstract Original Articles should be accompanied by an abstract of 250 words or less on a separate page, preferably in English and French, although the Journal will provide translation if required. Abstracts of original articles should consist of four paragraphs headed: Background (or objective), Methods, Results and Conclusions. Review articles should be accompanied by an abstract of 150 words or less.

- Acknowledgements including recognition of financial support should be typed on a separate page at the end of the text.

- The SI system (système international d'unités) should be used in reporting all laboratory data, even if originally reported in another system. Temperatures are reported in degrees celsius. English language text may use either British or American spelling, but should be consistent throughout.

- References should be numbered in the order of their citation in the text. Those cited only in tables and legends for illustrations are numbered according to the sequence established by the first iden- tification in the text of a particular table or illustration. Titles of journals should be abbreviated according to the style used in Index Medicus. References should list the names of up to five authors; if there are more, cite the first three, then et al. Provide the full title, year of publication, volume number and inclusive pagination for journal articles. For any reference cited as "in press", five copies of the article must accompany the author's manuscript. Do not reference unpublished or "submitted" papers; these can be mentioned in the body of the text and authors must provide five copies of "submitted" manuscripts. Avoid "personal communications" and, if necessary, include them in the body of the text, not among the references. Reference citations should not include unpublished presentations or other non-accessible material. Books or chapter references should also include the place of publication and the name of the publisher. Examples of correct forms of reference follow:

\section{Journals}

Yang JF, Fung M, Edamura R, et al. H-Reflex modulation during walking in spastic paretic subjects. Can J Neurol Sci 1991; 18: 443-452.

Chapter in a book

McGeer PL, McGeer EG. Amino acid neurotransmitters. In: Siegel GJ, Albers RW, Agranoff BW, Katzman R, eds. Basic Neurochemistry. Boston: Little, Brown \& Co., 1981: 233-254.

- Illustrations Submit five original sets of illustrations. We will not return illustrations; therefore, authors should keep negatives for all photographs. Submit high quality glossy black and white photographs preferable $127 \times 173 \mathrm{~mm}\left(5^{\prime \prime} \times 7^{\prime \prime}\right)$. Original artwork and radiographs should not be submitted. The additional cost of coloured illustrations must be borne by the author; quotations are available upon request from the Journal office. Identify each figure with a label at the back indicating top, figure number and first author. Letters and arrows applied to the figures to identify particular findings should be professional appliques suitable for publication. Photomicrographs should include a calibration bar with a scale indicated on the figure or in the legend. Legends for illustrations should be typed on a separate page from the illustrations.

- Tables Type tables double-spaced on pages separate from the text. Provide a table number and title for each. Particular care should be taken in the preparation of tables to ensure that the data are presented clearly and concisely. Each column should have a short or abbreviated heading. Place explanatory matter in footnotes, not in the heading. Do not submit tables as photographs.

- Review articles on selected topics are also published. They are usually invited, but unsolicited reviews will be considered. It is recommended that authors intending to submit review articles contact the Editor in advance.

- Letters to the Editor concerning matters arising in recent articles are welcome. Letters should be limited to two double-spaced pages and may include one illustration and a maximum of four references.

- Permissions and Releases Any non-original material (quotations, tables, figures) must be accompanied by written permission from the author and the copyright owner to reproduce the material in the Journal. Photographs of recognizable persons must be accompanied by a signed release from the legal guardian or patient authorizing publication. 
Lorsque la phénytoïne ou la carbamazépine ne réussissent pas à procurer une maîtrise adéquate des crises partielles chez l'adulte.

\section{AJOUTER NEURONTIN}
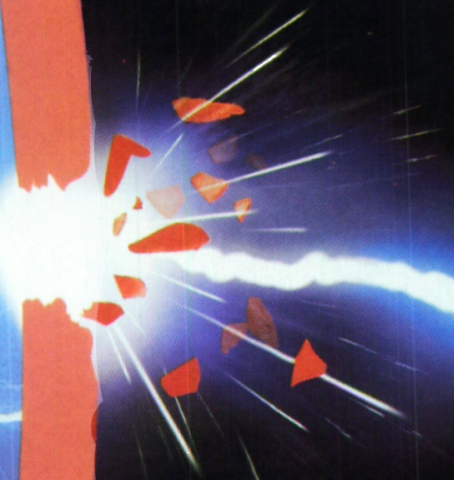

Aucune interaction pharmacocinétique avec les anticonvulsants traditionnels n'a été observée avec Neurontin. Il est par conséquent facile de l'utiliser comme traitement adjuvant avec les antiépileptiques existants'.

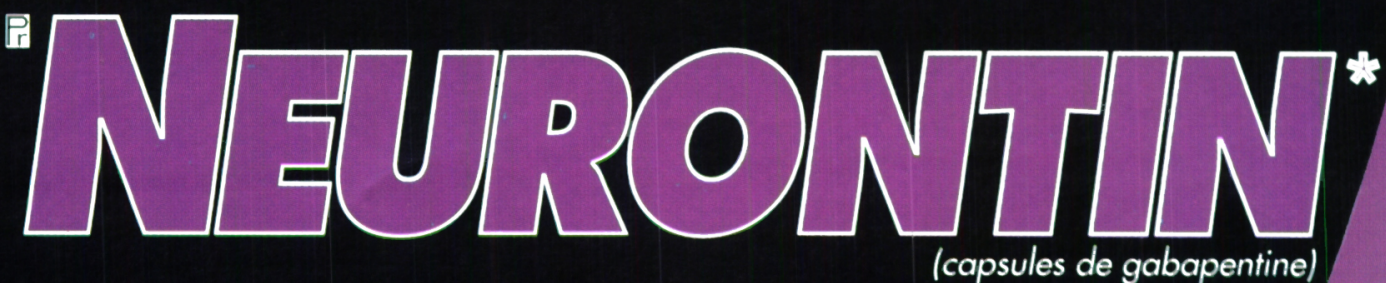

\section{Facile à utiliser comme adjuvant}

Neurontin est indiqué comme traitement d'appoint pour les patients dont l'état épileptique n'est pas bien maîtrisé par les traitements traditionnels. Les effets secondaires les plus courants qui n'ont pas été observés à une fréquence équivalente chez les patients sous placebo sont les suivants : somnolence, étourdissements, ataxie, fatigue, nystagmus et tremblements. Étant donné que Neurontin était administré le plus souvent en association avec d'autres antiépileptiques, il était impossible de déterminer à quel(s) agent(s) les effets secondaires étaient associés.

\section{(B) PARKE-DAYIS}




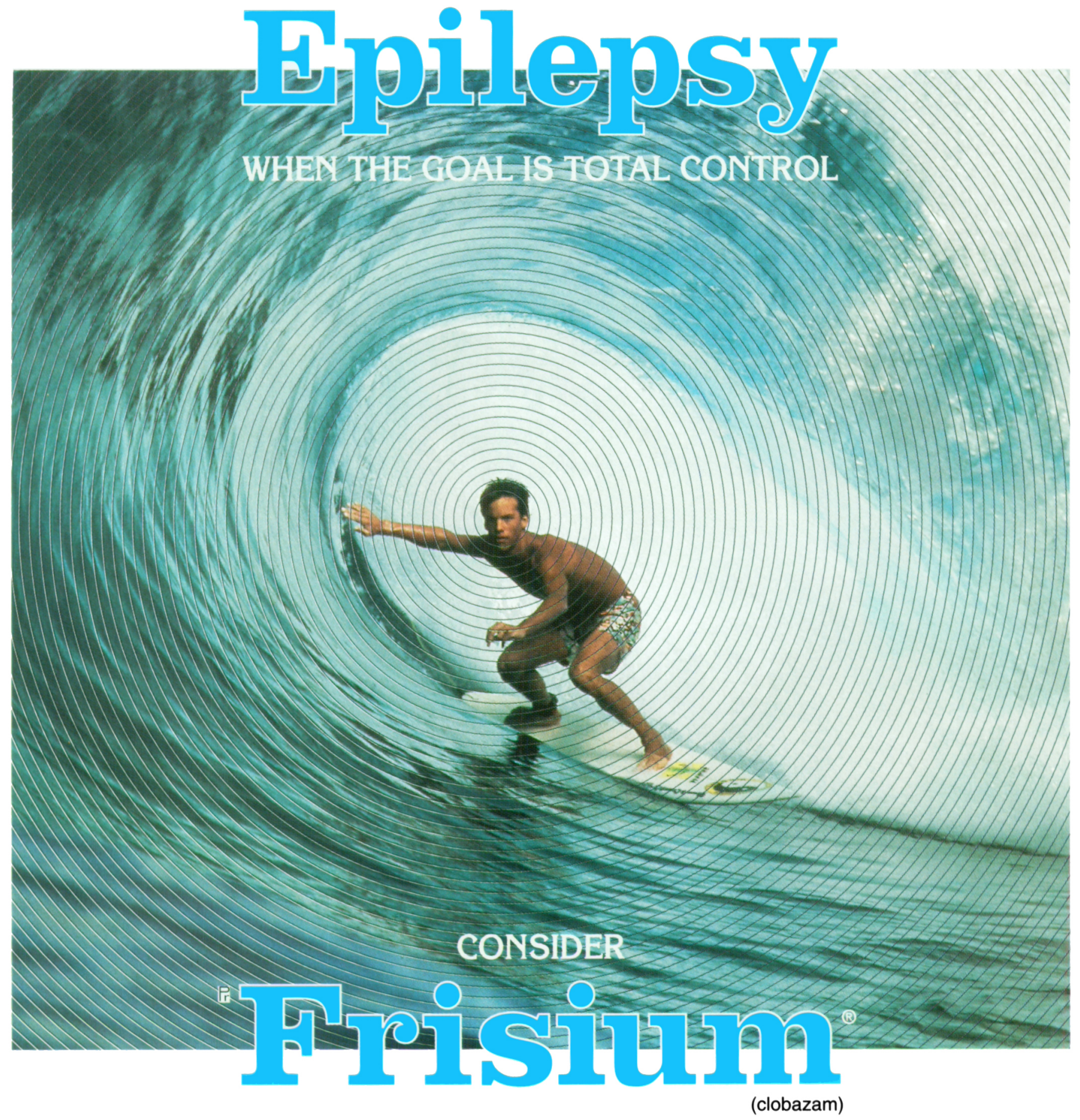

- Impressive degree of complete seizure control. ${ }^{1}$

- Effective in all seizure types in pediatric and adult patients. ${ }^{2}$

- Frisium is a "remarkably effective and [generally] safe add-on anti-epileptic drug".

- Once-daily dosage, preferably at bedtime.

\section{For a comprehensive approach to seizure control}

*Daily dose can be divided for some patients.

Frisium is indicated as adjunctive therapy in epileptic patients not adequately stabilized with their current anticonvulsant therapy. As with all benzodiazepines, patients (particularly geriatrics) should be cautioned accordingly. Most frequent adverse effects (> $1 \%$ ) include ataxia, weight gain, dizziness and nervousness. 